\title{
Institutionalization of Firm Environment in Conditions of Growing Turbulence
}

\author{
Bagautdinova N.G. ${ }^{a}$ \\ Safiullin L.N. ${ }^{b}$ \\ Minnahmetov R.R.c1 \\ a bc Kazan Federal University, Kazan, 420008, Russia \\ 1Email address: verkbund@gmail.com
}

\section{Doi:10.5901/mjss.2014.v5n12p55}

\begin{abstract}
The article deals with theoretical-methodological approach to the content of process of an institutionalization of factors of sustainable development of firm in conditions of growing uncertainty, and also proves practical recommendations providing effective institutional design of environment of economic agents. Measures of institutional design of environment of firm with participation of expanded structure of economic agents (the state, firm and its contractors, households) who influence level of substitution and complementarity of factors, their number, speed of changes in structure of elements of environment, quality and reliability of information are developed.
\end{abstract}

Keywords: environment institutionalization, transactional expenses, turbulence of environment, institutional design of environment of firm, enforcement of contracts.

\section{Introduction}

The export-oriented model of development of Russian economy with preservation of priority of extracting sectors caused essential dependence of business entity on limited quantity of factors of environment among which the crucial role belongs to environment of the world markets of energy carriers. It substantially defined non-competitiveness of real sector of Russian economy and instability of development of its subjects. Lack of effective mechanisms of counteraction to destabilizing factors, first of all, to considerable reduction of consumption of energy resources and reduction of prices of them in conditions of world financial crisis led to that outputs in the Russian Federation (RF) 2008-2009 were reduced. Now preservation of raw orientation of development of Russian economy is the factor destabilizing its state.

Competitiveness and stability of functioning of certain economic operator, condition of system of their safety is substantially defined by character of environment that allows considering firm (enterprise) as open system and an integral part of economic space. Ability of the economic operator to react adequately and in due time to indignation of environment makes essence of its adaptation potential which along with production, financial, labor, investment and innovative potentials defines the directions and dynamics of development of firm. Regardless of form of ownership, an organizational and legal form and a type of economic activity firms are in situation of steady turbulence, no predictability of possible changes of factors of environment account of which acts as a necessary condition of making decisions on directions, forms and methods of allocation of resources. The firm's objective assessment of condition of environment allows creating strategy which provides overcoming of dominating role of factors of uncertainty in relation to the subject of managing in favor of offensive strategy of formation of external conditions that gains special relevance in conditions of globalization and formation of qualitatively new formats of interaction of separate enterprises, the national states in world economic space, emergence of new risks of the business activity caused by the introduction of a human civilization on a stage of information society.

The analysis of sources of stability of economic systems of all levels testifies that among them the essential role is carried out by institutional factors which aren't fully considered within neoclassical and Keynesian paradigms. At the same time the neglect of them doesn't allow formulating effective recommendations to economic operators and public authorities concerning ways of realization of model of sustainable development taking into account turbulence of environment. Thus, development and realization of strategy of active influence from economic agents on environment, being characterized high level of turbulence, for the purpose of increase of indicators of economic development assumes need of reconsideration of problem of growing uncertainty of the market and related problem of stability of economic 
systems that predetermined a choice of a subject of research, its theoretical and practical importance.

Works of representatives of the classical, neoclassical and Keynesian directions who considered this problem from positions of the theory of maximizing profit (A. Smith, D. Ricardo, A.Marshall, Y.G.Tyunen, J. M. Keynes, etc.) are devoted to research of a problem of a sustainable development of certain economic operators. K. Marx and F. Engels investigated behavior of enterprises from the point of view of achievement of effect taking into account growth of influence of organic structure of capital by rate of return that allowed revealing a dual role of this factor: on the one hand, new forms of ensuring risks lead to fall of average rate of return, and on the other - express increase of production rates.

Questions of application of institutional approach to research of uncertain environment are presented in works of foreign representatives of this direction - J. Buchanan, J. Galbraith, T.Veblen, U. Mitchell, J. Colt, S. Cornell, R. Coase, G. Myrdal, D. North, O. Williamson, etc.

Despite considerable amount of works $[4 ; 7 ; 8 ; 11]$, devoted to various aspects of problem of stability, there is no formed and approved concept of institutional design of economy and its separate sectors, focused on stability which causes need of search of the new methods and forms of organization of various aspects of activity of economic agents for this direction.

\section{Methodology}

According to the principles of the neo-institutional concept, the firm in work is treated as a network of long-term bilateral contracts between owners of resources and the central agent in occasion of idiosyncratic or low-specialized assets which replace the market of factors of production and final goods that causes a small role of price signals owing to ensuring coordination by means of authoritative orders. As advantage of such organization of contract relations acts completeness of the contract which provides lack of need for ex-post management of the contract, and also lack of information asymmetry and the problem prevention "principal - agent".

The border of firm separating a network of contracts within vertical integration from environment, is defined by limited rationality of businessman that doesn't allow him to provide the most effective allocation of assets, and also increase in volume of transmitted data that causes advantages of system of price signals as the mechanism of movement of information. Thus, borders of firm are defined by a ratio of expenses of organization of one additional transaction in firm and expenses of implementation of the same transaction in the open market or expenses of its organization by another firm. In the conditions of society information system development unevenness of distribution of information on properties of assets and subjects of contract relations between contractors increases which acts as a source of high expenses of restoration of symmetry in possession of it. The analysis of the contract relations testifies to additional expenses of the subject of managing, connected with increase of level of uncertainty of functioning of external factors which account acts as the necessary condition of effective use of assets of firm.

\section{Completion}

Level of uncertainty of environment and nature of reaction from the subject of managing define the maintenance of the mechanism of interaction of firm with subjects of environment which provides a choice of strategy of its development. Depending on the level of uncertainty it is expedient to allocate the environment, being characterized high, average and low turbulence. In turn, depending on sources of change of environment it is expedient to allocate firms, active concerning their elements, and firms concerning which elements of environment dominate. Due to the offered approach it is expedient to allocate 6 possible models of interaction of firm and components of environment (table 1).

Table 1: Models of interaction of firm and environment components

\begin{tabular}{|c|c|c|c|}
\hline \multirow{2}{*}{ Firm strategy } & \multicolumn{3}{|c|}{ Level of uncertainty of environment } \\
\cline { 2 - 4 } & High & Average (faltering) & Low \\
\hline Adaptive strategy of firm & + & $+/-$ & +++ \\
\hline Constructive strategy of firm & +++ & $+/-$ & + \\
\hline
\end{tabular}

+ - probability of a choice of this strategy;

$+/$ - the choice of alternative types of strategy is equally possible.

Constructive strategy of development of firm is preferable in conditions of high level of uncertainty that causes need of formation the external conditions the economic operator. Adaptive strategy can be effective in case of the low level of 
uncertainty of environment which factors dominate during the developing and acceptance of administrative decisions by the central agent of firm. In this case subject and object structures of the external contracts signed by firm, and also in many respects results of their realization are defined by environment structure.

As indicators of uncertainty of environment can act the rate of inflation, unemployment rate, rates of a gain of gross domestic product, etc. [3; 5, 12]. As indirect indicators of a share of the firms which have chosen constructive strategy of development, act indicators of innovation of the Russian economy (table 2).

Table 2: Indicators of an assessment of innovative development of national and regional social and economic systems [2]

\begin{tabular}{|c|c|c|c|c|c|}
\hline $\begin{array}{c}\text { Indicator } \\
\text { code }\end{array}$ & Indicator name & $\begin{array}{c}\text { Actual data } \\
\text { of } 2011 .\end{array}$ & $\begin{array}{c}\text { Standard of } \\
\text { an } \\
\text { innovative } \\
\text { state }\end{array}$ & $\begin{array}{l}\text { Comparison of } \\
\text { the actual and } \\
\text { ideal values, \% }\end{array}$ & $\begin{array}{c}\text { Source of value (standard) for an } \\
\text { assessment of an innovative state in modern } \\
\text { conditions }\end{array}$ \\
\hline $\mathrm{H} 1$ & $\begin{array}{l}\text { Share of internal expenses for } \\
\text { researches and development } \\
\text { in gross domestic product, } \%\end{array}$ & 1,03 & 3,00 & 34,33 & $\begin{array}{l}\text { Recommendations of the "Lisbon strategy" } \\
\text { for EU countries }\end{array}$ \\
\hline $\mathrm{H} 2$ & $\begin{array}{l}\text { Number of the granted } \\
\text { patents for } 10000 \text { people of } \\
\text { the population, unit. }\end{array}$ & 2,21 & 6,26 & 35,30 & $\begin{array}{l}\text { Average calculated value over the leading } \\
\text { world countries (G8 country) }\end{array}$ \\
\hline H3 & $\begin{array}{l}\text { Specific weight of the } \\
\text { organizations which were } \\
\text { carrying out technological } \\
\text { innovations, in total number of } \\
\text { the organizations, \% }\end{array}$ & 9,40 & 44,25 & 21,24 & \multirow{2}{*}{$\begin{array}{l}\text { "Strategy of development of science and } \\
\text { innovations in the Russian Federation for the } \\
\text { period till 2015", approved The } \\
\text { interdepartmental commission on scientific } \\
\text { and innovative policy (the protocol No. } 1 \text { of } \\
\text { February 15, 2006) }\end{array}$} \\
\hline $\mathrm{H} 4$ & $\begin{array}{l}\text { Specific weight of innovative } \\
\text { production (services) in a total } \\
\text { amount of production made } \\
\text { (rendered services), \% }\end{array}$ & 5,00 & 18,00 & 27,78 & \\
\hline H5 & $\begin{array}{l}\text { Ratio of the income and } \\
\text { expenses in international } \\
\text { market of licenses, shares } \\
\text { unit. }\end{array}$ & 0,44 & 1,23 & 35,92 & $\begin{array}{l}\text { The payments received and transferred } \\
\text { according to contracts on transfer of licenses } \\
\text { (an average over OECD countries) }\end{array}$ \\
\hline $\mathrm{H} 6$ & $\begin{array}{l}\text { Direction of a trend of change } \\
\text { of indicators of } \mathrm{H} 1-\mathrm{H} 5\end{array}$ & 1,03 & More than 1 & Corresponds & $\begin{array}{l}\text { Positive value of a trend for the last three } \\
\text { years }\end{array}$ \\
\hline $\mathrm{H} 7$ & $\begin{array}{l}\text { Existence of the infrastructure } \\
\text { providing functioning of } \\
\text { markets of improvements, } \\
\text { innovations and the related } \\
\text { services (quality indicator) }\end{array}$ & $\begin{array}{c}\text { poorly } \\
\text { developed }\end{array}$ & Is present & $\begin{array}{l}\text { doesn't } \\
\text { correspond }\end{array}$ & $\begin{array}{l}\text { The quality indicator characterizing a level of } \\
\text { development of innovative infrastructure }\end{array}$ \\
\hline
\end{tabular}

Now, despite existence of a large number of researches of the innovative relations [6; 10] there is no uniform methodical approach to definition of level of innovation of economic agents. In table 2 there are presented indicators of an assessment of innovative development of the national and regional social and economic systems, offered and used by state bodies in the Russian Federation, and also the indicators used by the international organizations and in foreign states. The revealed problems of innovative development of subjects of the Russian economy are connected with low level of efficiency of the institutional environment of the innovative relations, and also with absence of the accounting of factors of uncertainty when developing strategy of a sustainable development of economic operators.

For formalization of procedure of a choice between mechanisms of transactions management there was introduced parameter allowing to estimate in a complex (taking into account specificity, uncertainty of environment and frequency) transaction parameters. This parameter can be presented in the form of the following formula:

$\mathrm{B}=\mathrm{K} 1^{*} \mathrm{~S}+\mathrm{K} 2^{\star} \mid+\mathrm{K} 3^{*} \mathrm{~F}$,

where $\mathrm{B}$ - parameter reflecting characteristics of transactions within certain control and supervising function; $\mathrm{S}$ specificity of transaction; I - uncertainty of environment; F - frequency of commission of transactions; K1, K2, K3 coefficients of influence of specificity, uncertainty of environment and frequency on resultant parameter.

S, I, F are estimated by an expert method, for each control and supervising function assuming opportunity of involvement of experts and expert organizations for a scale, for example, from 0 to 10 . The scale of values of criterion of 
a choice in a general view is presented in figure 1.

Market Hybrid Hierarchic mechanism mechanism mechanism

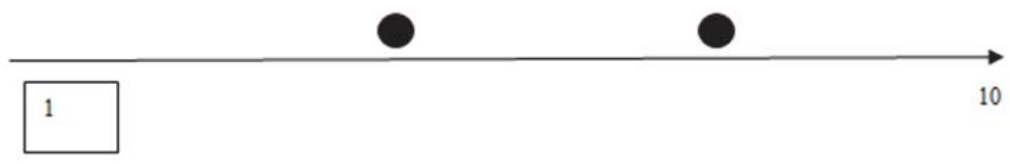

Fig. 1. Scale of values of parameter B

For implementation of calculations we will assume that influence of each of transaction parameters on resultant parameter is equivalent, therefore:

$$
B=\frac{1}{3} S+\frac{1}{3} I+\frac{1}{3} F
$$

\section{Conclusions}

Offered author's theoretical-methodical approach to the maintenance of forms and methods of institutional design of factors of environment of firm in conditions of its uncertainty proceeds from recognition of firm and its contractors as subjects of design of the state, and also households as owners of assets and consumers of end products. Activity of firm as subject of institutional design assumes development and implementation of strategy which provides adaptation of the economic operator to changing environment (change of organizational structure, a choice of the type of institutional agreement - vertical integration or hybrid organization, etc.) or the strategy directed on change of components of environment (increase of level of loyalty of consumers, implementation of socially responsible programs of development of the human capital, ensuring ecological equilibrium on placement territories, formation of partnership of agents and principals, forecasting of tendencies of development of environment and strategic planning of activity of the enterprises, etc.). Implementation of the offered actions will provide increase of level of stability of firm in conditions of growing uncertainty of environment.

\section{References}

Birger Wernerfelt. From Critical Resources to Corporate Strategy. — Journal of General Management, 1989, 14(3): 4-12.

Duysters, G., Kok, G. and M., Vaandrager (2000). «Crafting successful strategic technology partnerships». R\&D Management 29(4): 343-351.

Kim Clark and Takahira Fujimoto. Product Development Performance. — Boston: Harvard Business School, 1991

Safiullin, M.R., Elshin, L.A., Prygunova, M.I., Galyavov, A.A. (2013). Complex Analysis of Prospects of the Volga Federal District Regions Development: Methodology and Practice. World Applied Sciences Journal 27, 4, 508-511.

Miles R.E., Snow C.C. Fit, Failure and the Hall of Fame. N.Y.A Macmillan, 1994.

Fakhrutdinova E.V., Kolesnikova J.S., Suleimanov T.D., Khalikov A.L. The interrelation of the problems of the youth labour market and the "brain drain". Life Science Journal 2014; 11(6s): 473 - 477.

Moore M. Towards a Confirmatory Model of Retail Strategy Types: An Empirical Test of Miles and Snow // Journal of Business Research. 2005. N 58. H. 696-704.

Panasyuk M.V., Pudovik E.M., Sabirova M.E. Problems of labor market of modern Russia in conditions of stable economic growth. Life Science Journal 2014; 11(6s): 487 - 489.

Kirshin I.A., Datsyk A.A., Titov A.V. Forecasting the Dynamics of an Innovative Cycle. - World Applied Sciences Journal (Economics, Management and Finance). - 2013. - №27. - P. 197 - 201.

Glebova I.S., Sadyrtdinov R. and Rodnyansky D. Impact Analysis of Investment Attractiveness of the Republic of Tatarstan on Fixed Investments of its Leading Companies // World Applied Sciences Journal 26 (7): 911-916, 2013.

Porter M. (1987). From competitive advantage to corporate strategy. Harvard Business Review 65(1/3): 43-59.

Karasik E., Yagudin R., Leukhin A., Zagidullina V. Improvement of social policy towards the disabled in the Russian Federation. Life Science Journal 2014; 11(6s): $478-481$. 